\title{
Application of crossplot and prestack seismic-based impedance inversion for discrimination of lithofacies and fluid prediction in an old producing field, Eastern Niger Delta Basin
}

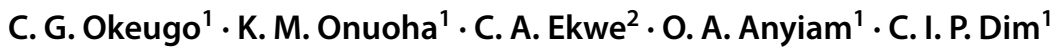

Received: 17 November 2017 / Accepted: 10 June 2018 / Published online: 21 June 2018

(c) The Author(s) 2018

\begin{abstract}
Lithofacies distributions and continuity are very important for proper reservoir development; and predicting the fluid types will also help in reducing uncertainties associated with characterizing hydrocarbon reservoirs. This study used Poisson impedance attributes and crossplots from prestack seismic inversion and well logs to discriminate and predict hydrocarbonfilled reservoirs in the Bumma Field, Greater Ughelli Depobelt, Niger Delta Basin. Seismic inversion and well log data were integrated to image and characterize lithofacies at reservoir zones of interest. A supervised model-based simultaneous inversion of Poisson impedance (PI) and crossplot was carried out on the prestack seismic data to understand the lithofacies classification and fluid types. Four classifications of lithofacies (clean sand, sandyshale, shaly-sand and shale) were discriminated based on the well log crossplot between gamma ray and Poisson impedance. The sand lithofacies shows low values of gamma ray $(<65 \mathrm{API})$ and $\mathrm{PI}(<-100 \mathrm{ft} / \mathrm{s} * \mathrm{~g} / \mathrm{cc})$ while shale lithofacies possesses high values of gamma ray $(>65$ API) and PI $(>-100 \mathrm{ft} / \mathrm{s} * \mathrm{~g} / \mathrm{cc})$. Also, well log and inverted results from PI showed that values with less than $-100 \mathrm{ft} / \mathrm{s} * \mathrm{~g} /$ cc represent hydrocarbon-filled sand, whereas greater values represent brine and shale. These classifications provide better decision in predicting and discriminating lithofacies accurately. Furthermore, generated map revealed the presence of hydrocarbon-filled reservoirs in a northeast-southwest trending meandering channel. The successful application of crossplot and seismic-based impedance inversion will be helpful in discriminating lithofacies and predicts fluids for accurate location of new wells for optimum production from the field.
\end{abstract}

Keywords Acoustic impedance $\cdot$ Cross-plot $\cdot$ Lithofacies $\cdot$ Poisson impedance $\cdot$ Prestack seismic data $\cdot$ Simultaneous inversion

\section{Introduction}

In the Niger Delta basin, the search for more hydrocarbons has, with time, shifted from onshore to near shelf and now to the deep water. Although, it is believed that the high cost of operations in deep water environments, followed by inability to characterize lithofacies and predict fluid types accurately across the basin depobelts are few major factors to contend with. Generally, the prediction of lithofacies

$\triangle$ C. G. Okeugo

chukwudike.okeugo@unn.edu.ng

1 Department of Geology, University of Nigeria, Nsukka, Nigeria

2 Department of Geology and Geophysics, Federal University Ndufu-Alike Ikwo, Ikwo, Nigeria and fluid type have over the years pose great challenge to reservoir geologists and geophysicists working on the old producing fields (discovered in the late 1950s with oil production from 1961) in onshore Niger Delta basin. Although, recent advances in seismic technology have led to development of methods such as Poisson impedance (PI) inversion, lambda-mu-rho inversion, elastic impedance inversion, EI and rock physics template modelling, and RPT to help characterize lithofacies and predict fluid types (Coulon et al. 2006; Singh et al. 2007; Ekwe et al. 2012; Tian et al. 2010; Sharma and Chopra 2013; Farfour et al. 2015; Tucovic et al. 2016). Advances on the use of prestack migrated seismic (PreSTM) data have tremendously helped in characterizing lithofacies and predicting reservoir properties with minimum error thereby reducing the numbers of dry wells and drilling risks in some basins of the world (Ma 2002; Russell 2014). Characterizing lithofacies and predicting fluid types from 
the Niger Delta basin using prestack migrated seismic data and well $\operatorname{logs}$ requires great skill and better understanding of seismic inversion techniques. Numerous studies have been conducted on the use of different seismic inversion types to characterize lithology and predict fluid types in Niger Delta basin. Most of the studies focused on the use of simultaneous, deterministic and geostatistical inversion to construct reliable earth and petrophysical models (Omodu et al. 2007; Ujuanbi et al. 2008; Nwogbo et al. 2009). One main advantage of using prestack seismic inversion for constructing reliable earth model and characterizing lithofacies is based on the ability of the technique to extract more information (such as shear velocity, Vs) from seismic data to better discriminate reservoir and non-reservoir rocks that are not answered by poststack seismic inversion.

The study area falls within the southern part of the Bumma Field (Fig. 1), which Reijers (2011) reported as being shalier than the northern part of the field, thus having lower chances of productive reservoirs. Shell Petroleum Development Company Internal Report, (2007) highlighted that the lack of productive reservoirs in the southern part of the field have significantly led to drilling marginal and dry wells (Table 1), so there is need to adopt an improved technique such as cross-plot analysis of Poisson impedance
Table 1 Wells showing status of production in the selected area of study

\begin{tabular}{lll}
\hline Well name & Spud date & Status \\
\hline AG & 1974 & Dry \\
AG-002XX & 1974 & Dry \\
AB & 1961 & Oil/gas \\
A & 1992 & Oil/gas \\
B & 1965 & Oil/gas \\
C & 1989 & Gas \\
AW-00XX & 1980 & Marginal \\
NKIX-001XX & 1977 & Marginal \\
ALB-001XX & 1965 & Marginal \\
\hline
\end{tabular}

and its inversion to discriminate lithofacies and predict fluid types in Bumma Field. The Poisson impedance was first published by Quakenbush et al. (2006) and they derived the attribute seismically by combining the discrimination characteristics of Poisson's ratio along with density, both of which are parameters useful in reservoir delineation. Also, several works have highlighted Poisson impedance as a very favorable attribute for identifying new prospect and characterizing clastic reservoir (Mazumdar 2007; Omodu

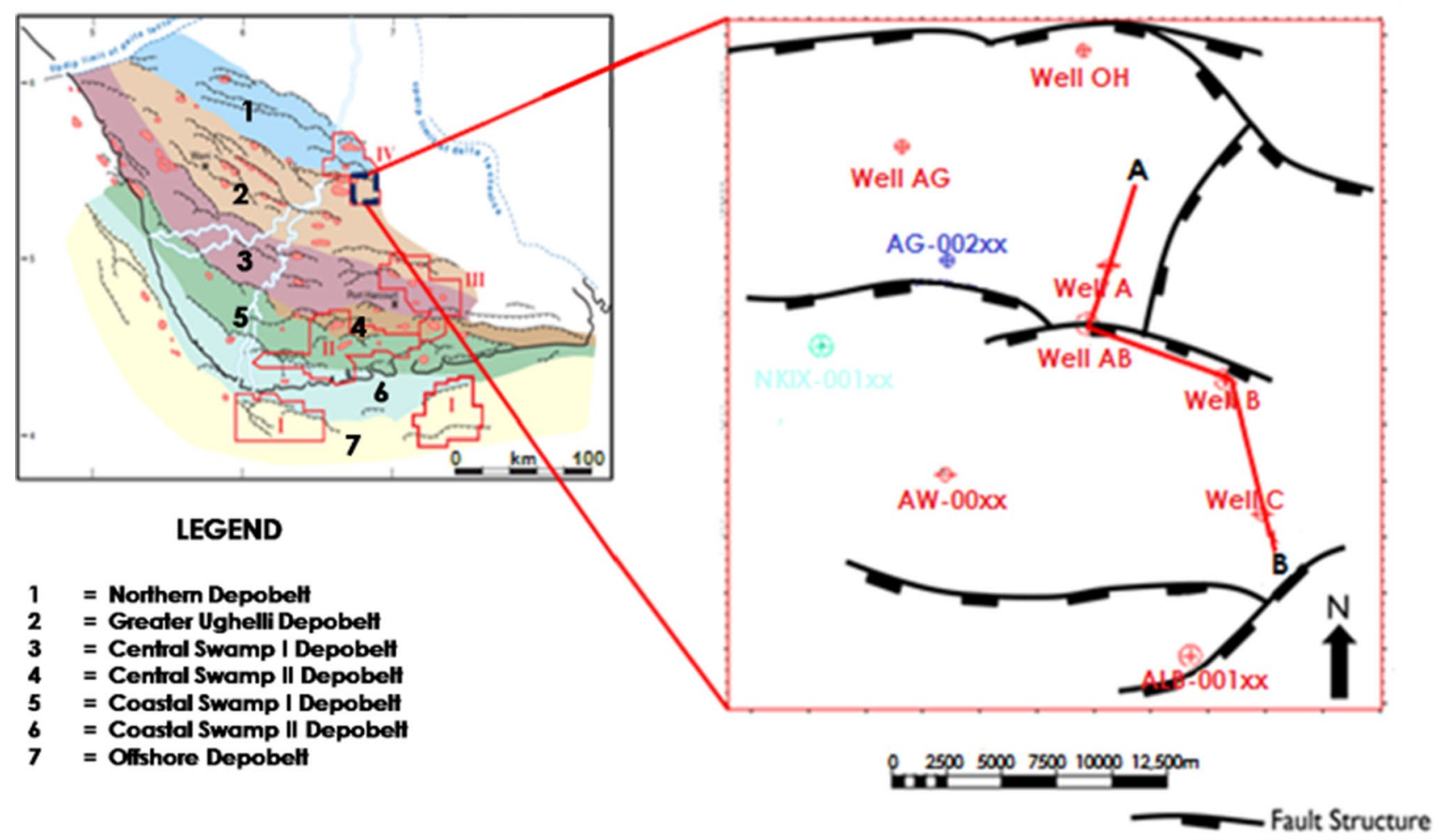

Fig. 1 A Niger Delta view showing position of Bumma Field, well positions, correlation line across major fault system between northern (a) and southern (b) parts of the field 
et al. 2007; Tian et al. 2010; Zhou and Hilterman 2010; and; Sharma and Chopra 2013). Therefore, the main aim of this study is to use cross-plot analysis and seismic simultaneous inversion-derived Poisson impedance to discriminate lithofacies and predict fluid types associated with H-reservoirs (comprising of H1, H4 and H5 sands) in Bumma Field.

\section{Geologic background}

Bumma field is located in the Greater Ughelli Depobelt of the onshore Niger Delta basin. The stratal package within the study area is formed from a major regressive cycle that resulted in deposition of allocyclic units of transgressive marine sand, marine shale, shoreface and fluvial back swamp deposits (Reijers 2011). The three lithostartigraphic units in the study area are from the bottom: the pro-delta facies of Akata Formation, parallic delta front facies of Agbada Formation and continental facies of Benin Formation (Fig. 2a). The Akata Formation is the oldest of the three formations with age ranging from Eocene to recent (Reijers et al. 2011; Lawrence et al. 2002). They are deep marine shale and serve as source rock (Short and Stauble 1967).The Akata shales formed during the early development stages of Niger Delta progradation and are typically under-compacted and overpressured. The shales also form diapiric structures including shale swells and ridges which often intrude into overlying Agbada Formation (Fig. 2b). It is exposed in the inland, north-eastern part of Niger Delta as the Imo shale. The Benin Formation is the youngest and comprises the top part of the Niger Delta clastic wedge, from the Benin-Onitsha area in the north to beyond the coast line (Short and Stauble 1967). The Agbada Formation overlies the Akata Formation and constitutes the main reservoir and seal for hydrocarbons accumulation in the Niger Delta. The formation occurs throughout Niger Delta clastic wedge and has a maximum thickness of about 13,000 feet (Doust and Omatsola 1989). The lithologies consist of alternating sands, silts and shales, arranged within 10-100 feet successions, and defined by progressive upward changes in grain size and bed thickness. The strata are generally interpreted to have been formed in fluvial-deltaic environment. The top of the formation is recent, and its base extends to a depth of 4600 feet. The base is defined by the youngest marine shale. Shallow parts of the formation are composed entirely of non-marine sand deposited in alluvial or upper coastal plain environments during progradation of the delta (Doust and Omatsola 1989).

The structural and stratigraphic settings of the field are mainly controlled by pre- and syn-sedimentary tectonic elements that responded to variable rates of subsidence and sediment supply during Late Eocene to Oligocene times (Doust and Omatsola 1990; Reijers 2011). Structurally, the macrostructures found in the area, according to Evamy et al.
(1978); Stacher (1995); Reijers (2011), range from simple rollover anticlines, multiple growth faults, antithetic faults and collapsed crest faults (Fig. 2c) with most of these faults offsetting at different parts of the Agbada Formation and flattening into Eocene detachment planes near the top of the Akata Formation (Reijers et al. 1997).

The stratigraphic setting, according to Orife and Avbovbo (1981); Petters (1984); SPDC Internal Report (2007) witnessed the cutting of Opuama Channel into the Orogbo megasequence $(34.4 \mathrm{Ma})$ in the western part of the delta leading to channel formation in the northern section of the active Greater Ughelli Depo-belt as a result of sea level fall at 35.4 Ma. Locally, the sequences deposited are characterized by proximal deltaic deposits and channel units that are separated by laterally extensive shale packages that represent flooding episodes, as shown in Fig. 3.

\section{Materials and methodology}

Available dataset used for this study include a full 3-D Prestack Time Migration (PreSTM) seismic volume and suites of wire line log comprising gamma ray, density-neutron, resistivity, shear and compressional velocity from nine wells as shown in Table 2. The PreSTM seismic volume and three wells (A, C and AG-002XX) were quality-checked (QC) and prepared for seismic simultaneous inversion process, before loading them into the Hampson Russell CE8IR4.4.1 software. Essential log data required for the inversion workflow (Fig. 4) are P-wave sonic, S-wave sonic, density and check shots logs.

\section{Theoretical background}

\section{Prestack seismic simultaneous inversion}

Prestack seismic inversion is a stratigraphic deconvolution technique that has, over the last couple of years, been used for reservoir characterization due to its sensitivity to resolve thin-bed tuning for increased stratigraphic resolution in many cases (Duboz et al. 1998; Veeken and Silva 2004). The primary aim of this inversion technique is to obtain reliable estimates of acoustic impedance (Zp), shear impedance (Zs), compressional velocity and shear velocity ratio, $\mathrm{Vp} / \mathrm{Vs}$ and Poisson ratios attributes from reflection amplitude, travel time and waveform data at non-normal incidence for more robust interpretation of lithology and fluid content (Ma 2002; Hampson et al. 2005; Sen 2006). The estimations of these attributes are based on the relations of the incident, reflected, and transmitted longitudinal waves and shear waves on both sides of a plane interface (Singleton 2011), and this has been discussed by several authors; for instance Ma (2002) and (Sen 2006) highlighted that the

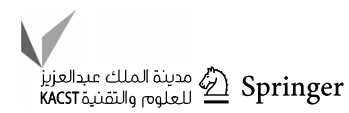


a

Delta-wide allocyclic units

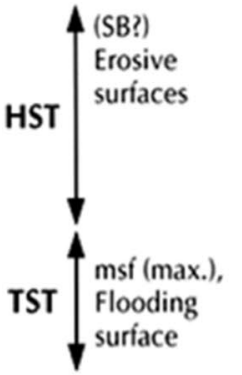

\section{Local allocyclic units}

E Fluvial backswamp deposits

DUpper shoreface sands

$C$ Lower shoreface

$B_{1}$ heteroliths

$B_{2}=$ Marine shale

A Transgressive marine sands

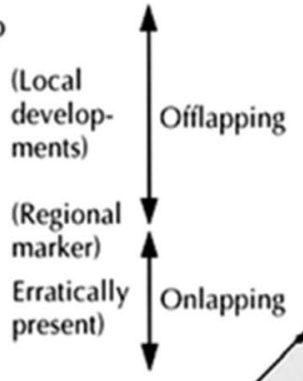

(2)

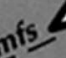

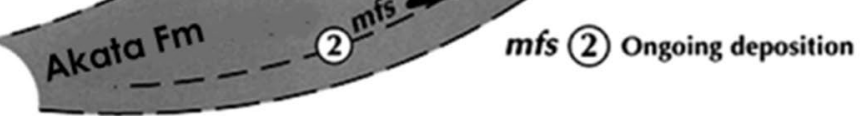

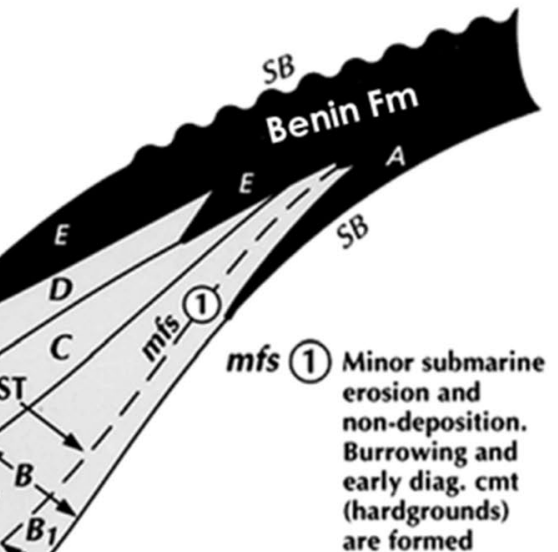

b

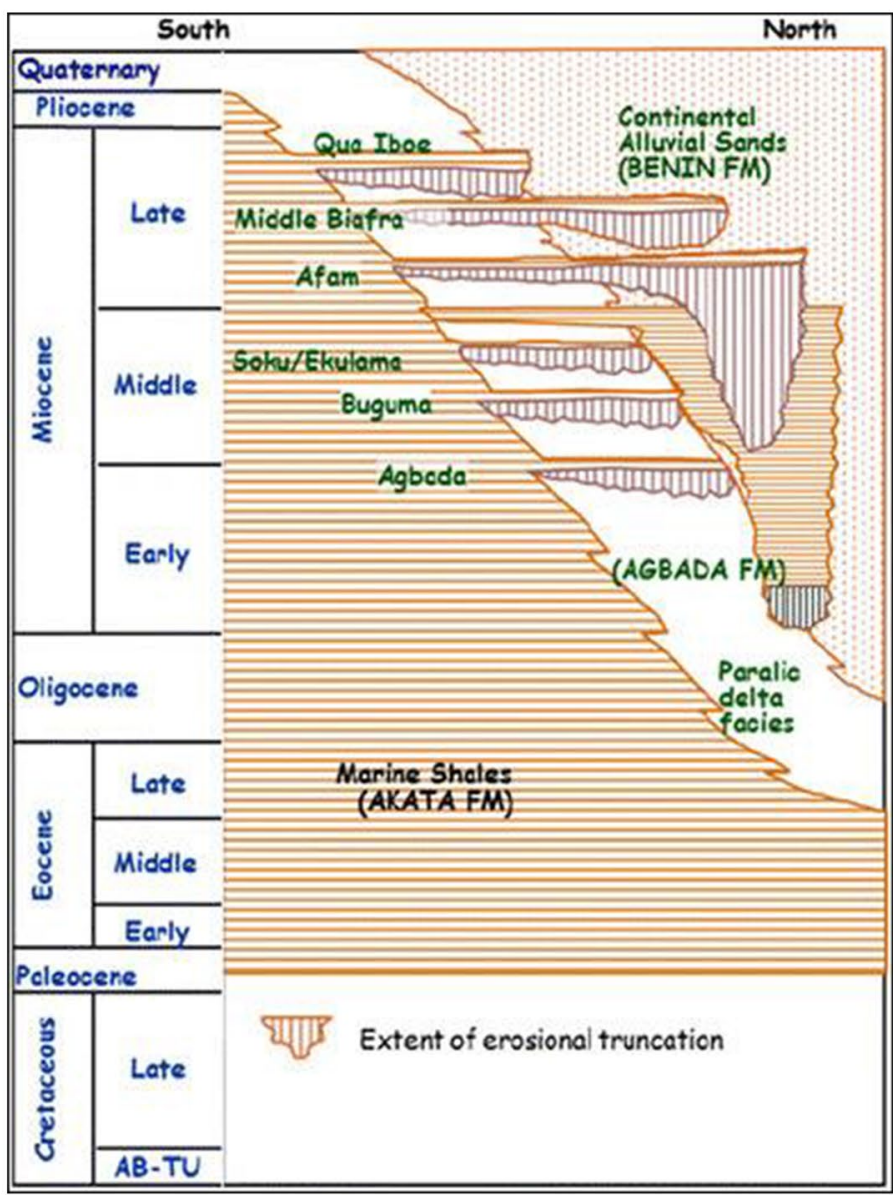

Fig. 2 a Schematic diagram showing the three allocyclic units of the three formations (adopted from Reijers 2011). b Stratigraphy of the Niger Delta showing the lithologic units of the three formations (adopted from Lawrence et al. 2002). c Generalized dip section of the Niger Delta showing the structural provinces of the Delta (adopted from Whiteman 1982) 


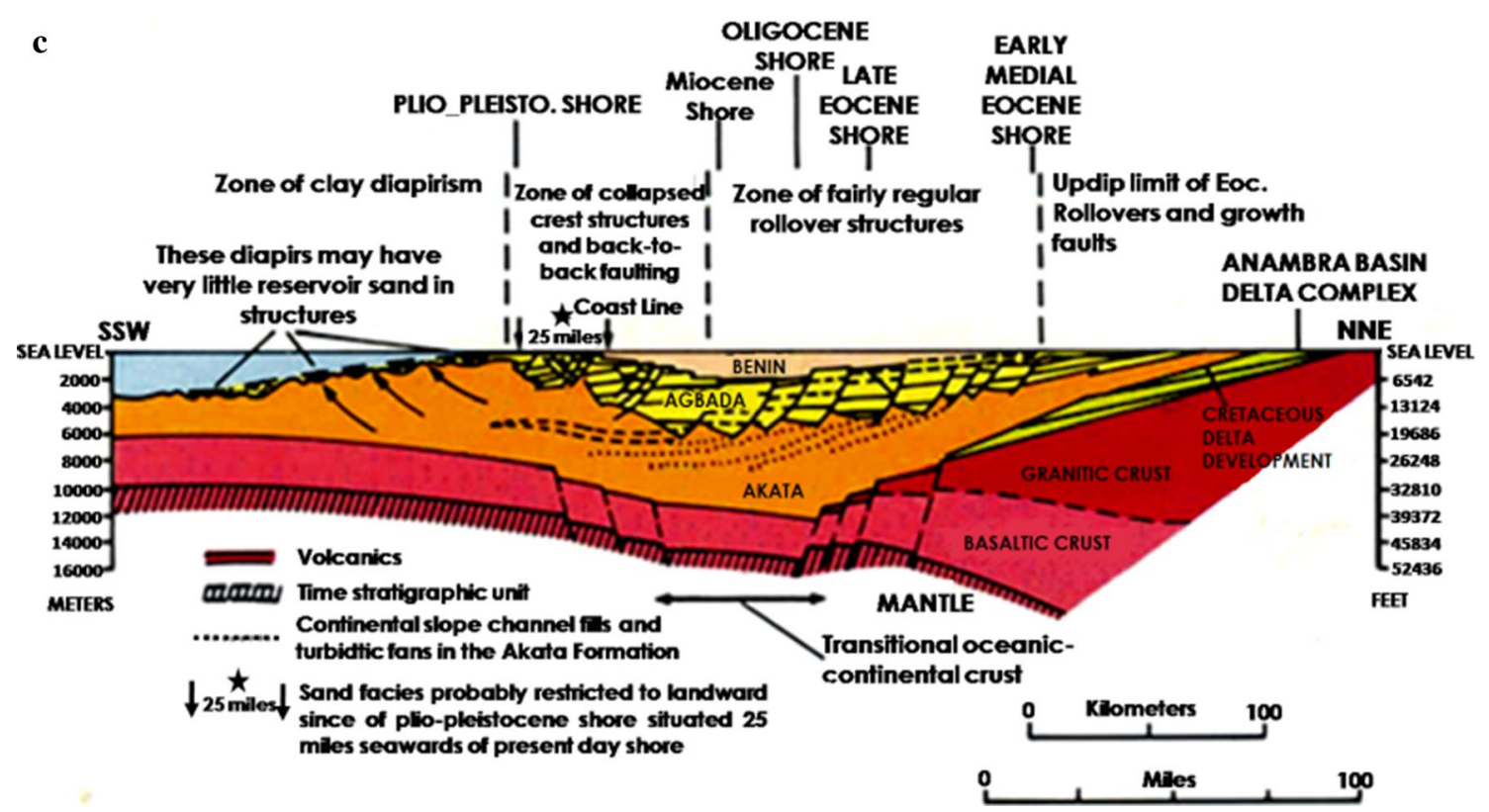

Fig. 2 (continued)

Zoeppritz equations are used to describe the relations of incident, reflected, and transmitted longitudinal waves and shearwaves on both sides of a plane interface. This firstorder approximation to reflectivity (Zoeppritz equations) is given by Aki and Richards (1980) equation as an approximate relationship between the $\mathrm{P}$-wave reflection coefficient $R(\theta)$ and the angle of incidence $\theta$ as follows:

$$
\begin{aligned}
R(\theta) \approx & \frac{1}{2}\left(\frac{\Delta V_{\mathrm{p}}}{V_{\mathrm{p}}}+\frac{\Delta \rho}{\rho}\right)-2\left(\frac{V_{\mathrm{s}}}{V_{\mathrm{p}}}\right)^{2}\left(2 \frac{\Delta V_{\mathrm{s}}}{V_{\mathrm{s}}}+\frac{\Delta \rho}{\rho}\right) \\
& \times \sin ^{2} \theta+\frac{1}{2} \frac{\Delta V_{\mathrm{p}}}{V_{\mathrm{p}}} \tan ^{2} \theta
\end{aligned}
$$

where $V_{\mathrm{p}}$ is the average P-wave velocity between two uniform half-spaces, $V_{\mathrm{s}}$ is the average $\mathrm{S}$-wave velocity, and $\rho$ is the average density. The assumptions following the approximations are (1) that the relative changes of property $\left(\Delta V_{\mathrm{p}} / V_{\mathrm{p}}, \Delta V_{\mathrm{s}} / V_{\mathrm{s}}\right.$, and $\left.\Delta \rho / \rho\right)$ are small, (2) that the secondorder terms can be neglected, and (3) that $\theta$ is much less than $90^{\circ}$. Therefore, Eq. (1) can be rewritten in terms of P-wave and S-wave impedances as:

$$
\begin{aligned}
R(\theta) \approx & \left(1+\tan ^{2} \theta\right) \frac{\Delta Z_{\mathrm{p}}}{2 Z_{\mathrm{p}}}-8\left(\frac{V_{\mathrm{s}}}{V_{\mathrm{p}}}\right)^{2} \sin ^{2} \theta \frac{\Delta Z_{\mathrm{s}}}{2 Z_{\mathrm{s}}} \\
& -\left[\tan ^{2} \theta-4\left(\frac{V_{\mathrm{s}}}{V_{\mathrm{p}}}\right)^{2} \sin ^{2} \theta\right] \frac{\Delta \rho}{2 \rho}
\end{aligned}
$$

where $Z_{\mathrm{p}}=V_{\mathrm{p}} \rho$ is the average acoustic impedance, $Z_{\mathrm{s}}=V_{\mathrm{s} \rho}$ is the average shear impedance, $\Delta Z_{\mathrm{p}} / 2 Z_{\mathrm{p}}=1 / 2\left(\Delta V_{\mathrm{p}} / V_{\mathrm{p}}\right)+$ $\Delta \rho / \rho$ is the zero-offset $\mathrm{P}$-wave reflection coefficient, and $\Delta Z_{\mathrm{s}} / 2 Z_{\mathrm{s}}=1 / 2\left(\Delta V_{\mathrm{s}} / V_{\mathrm{s}}\right)+\Delta \rho / \rho$ is the zero-offset $\mathrm{S}$-wave reflection coefficient. Later, Fatti et al. (1994) simplified the P-wave reflection coefficient $R(\theta)$ by assuming that the third term in Eq. (2) involving $\rho$, only cancels for most $V_{\mathrm{s}} / V_{\mathrm{p}}$ ratios around 0.5 and small angles, and simplified the Zoeppritz's equations as:

$\mathrm{R}(\theta) \approx\left(1+\tan ^{2} \theta\right) \frac{\Delta \mathrm{Zp}}{2 \mathrm{Zp}}-8\left(\frac{\mathrm{Vs}}{\mathrm{Vp}}\right)^{2} \sin ^{2} \theta \frac{\Delta \mathrm{Zs}}{2 \mathrm{Zs}}$

This approximation has been used over time to extract the $\mathrm{P}$ - and S-impedance reflectivities by fitting the P-wave reflection amplitudes from CMP gathers. It is also believed that the background $\left(V_{\mathrm{s}} / V_{\mathrm{p}}\right)$ ratio must be known a priori, else $\mathrm{P}$ - and S-impedance reflectivity could produce a biased or physically unreasonable solution (Wang 1999). To overcome this limitation, Ma (2002) replaced $\left(V_{\mathrm{s}} / V_{\mathrm{p}}\right)$ by $\left(Z_{\mathrm{s}} / Z_{\mathrm{p}}\right)$, such that the reflection coefficients $R(\theta)$ are only a function of only three parameters: $Z_{\mathrm{p}}, Z_{\mathrm{s}}$ and $\theta$. Equation 3 then becomes,

$R(\theta) \approx\left(1+\tan ^{2} \theta\right) \frac{\Delta Z_{\mathrm{p}}}{2 Z_{\mathrm{p}}}-8\left(\frac{Z_{\mathrm{s}}}{Z_{\mathrm{p}}}\right)^{2} \sin ^{2} \theta \frac{\Delta Z_{\mathrm{s}}}{2 Z_{\mathrm{s}}}$

These forms the basis of a simultaneous inversion procedure that estimates acoustic and shear impedances $\left(Z_{\mathrm{p}}\right.$ and $\left.Z_{\mathrm{s}}\right)$ 
Fig. 3 Lithologic sequence from well A in northern part of the Bumma field. (31.3MFS, 32.4SB, 33.0MFS, 33.3SB, and c34.4_MFS are the maximum flooding surfaces and sequence boundaries defined over the Oligocene sequence)
Table 2 Data quality chat from wells in BUMMA Field

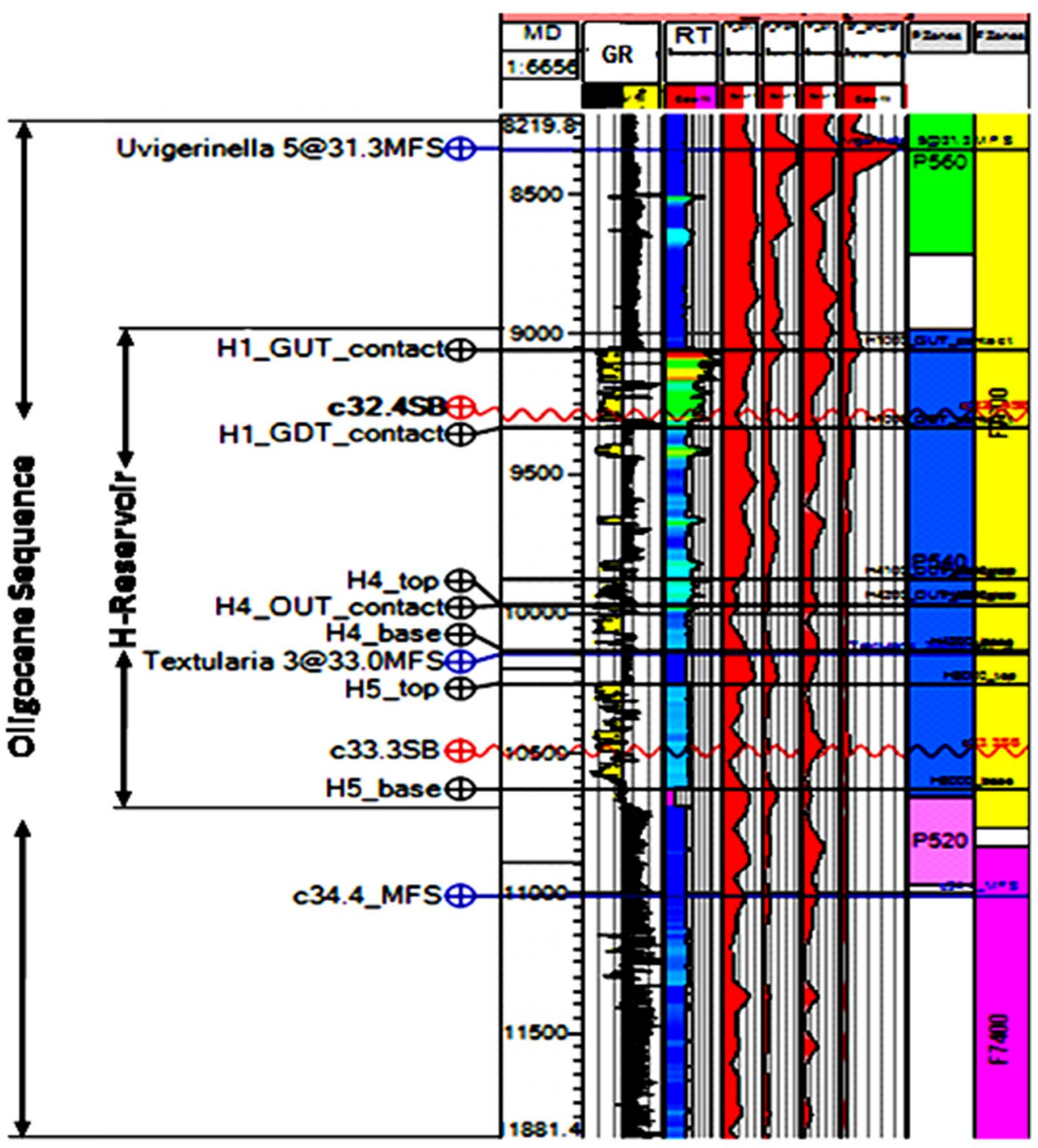

\begin{tabular}{|c|c|c|c|c|c|c|c|c|c|}
\hline \multirow[t]{2}{*}{ Well name } & \multicolumn{2}{|c|}{$\begin{array}{l}\text { Lithologic } \\
\operatorname{logs}\end{array}$} & \multicolumn{3}{|c|}{ Resistivity log } & \multirow{2}{*}{$\begin{array}{l}\text { Density } \\
\text { FDC }\end{array}$} & \multirow{2}{*}{$\begin{array}{l}\text { Neutron } \\
\text { CNL }\end{array}$} & \multirow{2}{*}{$\begin{array}{l}\text { Compres- } \\
\text { sional sonic } \\
\text { BCSL }\end{array}$} & \multirow{2}{*}{$\begin{array}{l}\text { Shear sonic } \\
\text { DSTM }\end{array}$} \\
\hline & SP & GR & $\mathrm{SN}$ & ILD & LLD & & & & \\
\hline $\mathrm{AG}$ & Yes & Yes & No & No & Yes & Yes & No & Yes & No \\
\hline AG-002XX & Yes & Yes & No & No & Yes & Yes & Yes & Yes & Yes \\
\hline $\mathrm{AB}$ & Yes & Yes & Yes & No & Yes & No & No & Yes & No \\
\hline A & No & Yes & Yes & No & Yes & Yes & Yes & Yes & Yes \\
\hline B & Yes & Yes & Yes & Yes & Yes & No & Yes & Yes & No \\
\hline $\mathrm{C}$ & Yes & Yes & Yes & Yes & Yes & Yes & Yes & Yes & Yes \\
\hline AW-00XX & No & Yes & Yes & Yes & Yes & Yes & Yes & No & No \\
\hline NKIX-001XX & NA & NA & NA & NA & NA & NA & NA & NA & NA \\
\hline ALB-001XX & No & Yes & Yes & No & Yes & No & No & Yes & No \\
\hline
\end{tabular}


Fig. 4 Schematic workflow of model-based simultaneous inversion for Poisson impedance extraction by combined use of seismic and well log data

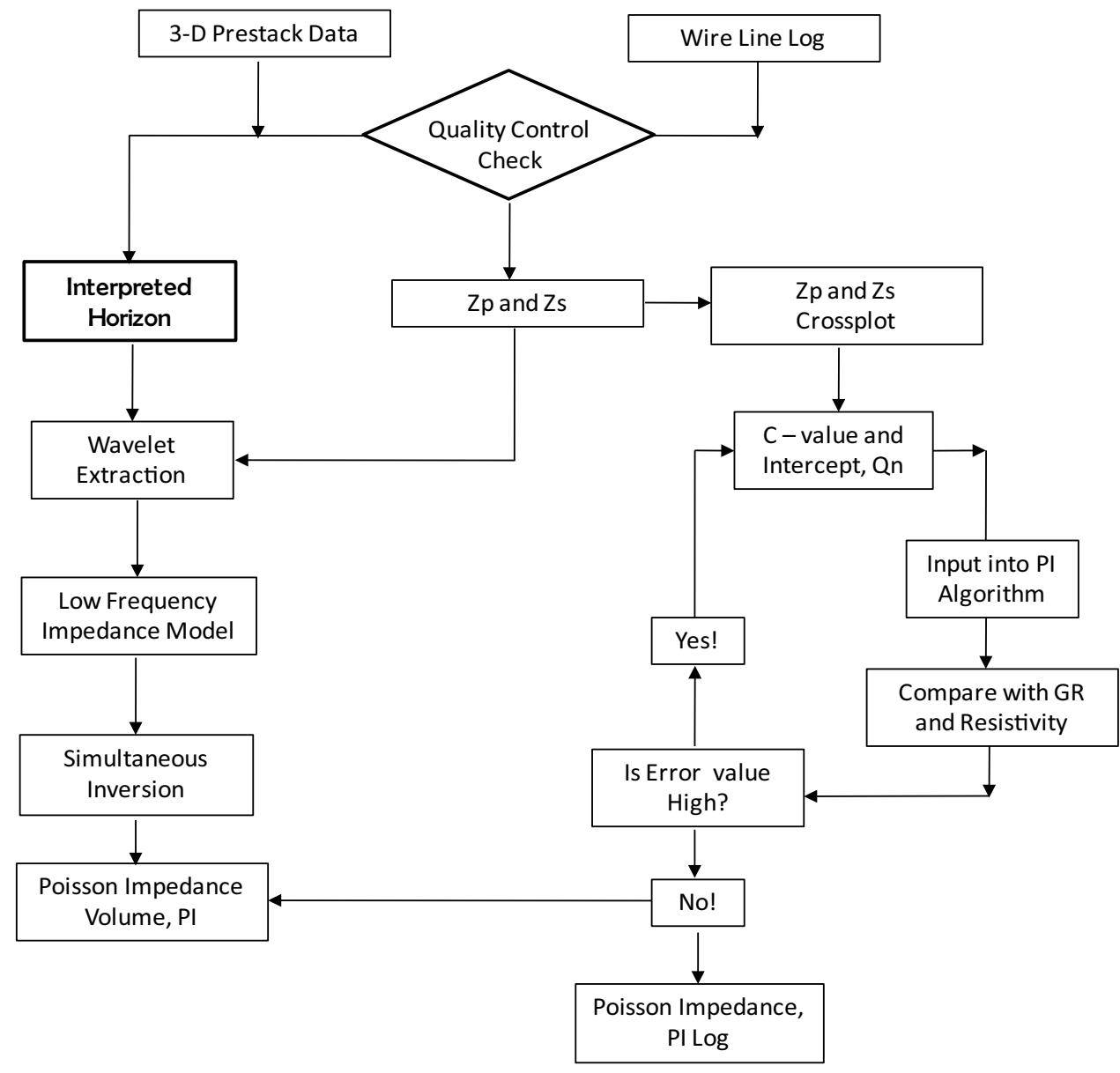

from prestack seismic gathers. The basic assumptions made from the approximation (Eq. 4) are that the earth has approximately horizontal layers at each common depth point and that each layer is described by both acoustic and shear impedances. Once acoustic impedance $Z_{\mathrm{p}}$ and shear impedance $Z_{\mathrm{s}}$ volumes have been created, they can be easily used to create other useful volumes, such as Poisson impedance, PI and lambda-rho, $\lambda \rho$ and mu-rho, $\mu \rho$, which are the product of density and the Lamé elastic constants $\lambda$ and $\mu$ (Goodway et al. 1997).

\section{Poisson impedance attribute (log and seismic)}

Poisson impedance is a relatively novel attribute and sensitivity tool developed for discriminating lithology and fluid content (Quakenbush et al. 2006). The Poisson impedance attribute is a set of combined impedances (acoustic and shear) that are optimized by axis rotation to produce better resolution of lithology and fluid content (Quakenbush et al. 2006 and; Sharma and Chopra 2013). The attribute has showed many successful applications in delineating hydrocarbon-filled and brine-filled sands from shales (Mazumdar 2007; Omudu et al. 2007; Zhou and Hilterman 2010; Tian et al. 2010; and; Nair et al. 2012). The mathematical Poisson impedance is defined as,

$\mathrm{PI}(t)=Z_{\mathrm{p}}(t)-C_{\mathrm{n}} * Z_{\mathrm{s}}(t)+Q_{\mathrm{n}}=Z_{\mathrm{p}}(t)--\left[\left(Z_{\mathrm{p}} / Z_{\mathrm{s}}\right)_{\text {wet }}\right]_{\mathrm{avg}} Z_{\mathrm{s}}(t)+Q_{\mathrm{n}}$

where $Z_{\mathrm{p}}(t)=$ Acoustic Impedance trace, $(\mathrm{ft} / s)(\mathrm{g} / \mathrm{cc})$

where $Z_{\mathrm{s}}(t)=$ Shear Impedance trace, $(\mathrm{ft} / \mathrm{s})(\mathrm{g} / \mathrm{cc})$

$C_{\mathrm{n}}$ or $\left[\left(Z_{\mathrm{p}} / Z_{s}\right)_{\mathrm{wet}}\right]_{\mathrm{avg}}=$ Rotation optimization Factor

(Generated from the slope of the $Z_{\mathrm{p}}(t)$

$$
-Z_{\mathrm{s}}(t) \text { crossplot) }
$$

$Q_{\mathrm{n}}=$ Intercept value at $Z_{\mathrm{p}}(t)$ axis

$\mathrm{PI}(t)=$ Poisson Impedance, $(\mathrm{ft} / s)(\mathrm{g} / \mathrm{cc})$

The lithology optimization factor $C_{\mathrm{n}}$ and Intercept $Q_{\mathrm{n}}$ were determined as slope and intercept values of the crossplot regression line between acoustic and shear impedance from well A which is the control well (Fig. 5). Generation of Poisson Impedance from well log as shown in Fig. 6a requires an input of the $C_{\mathrm{n}}, Q_{\mathrm{n}}$ and acoustic impedance 
$\left(Z_{\mathrm{p}}\right)$ and shear impedance $\left(Z_{\mathrm{s}}\right)$ into Eq. 5. Crossplot analysis between Poisson impedance with gamma ray log was also determined using well A to help understand lithofacies distribution with respect to classifying them as clean sand, sandy-shale, shaly-sand and shales at inter-well distances (Fig. 6b).

On seismic, Poisson impedance attribute was generated following seismic simultaneous inversion steps, which require independent volumes of acoustic impedance $\left(Z_{\mathrm{p}}\right)$ trace, and shear impedance $\left(Z_{\mathrm{s}}\right)$ trace. A zero-phased wavelet was extracted statistically from two wells (A and C) following the calibration of well to seismic as shown in Fig. 7a. Total of four horizons or reflection events (31.3MFS, 32.4SB, 33.0MFS and c34.4MFS) were picked as maximum flooding surfaces (MFS) and sequence boundary (SB) for the seismic inversion. Picked reflection events are based on the reversed polarity convention, which defines the peak as a decrease in acoustic impedance and trough as increase in acoustic impedance with depth (Fig. 7b). A low frequency model representing acoustic and shear impedances and density was generated to accurately perform inversion analysis as shown in Fig. 8. The main outputs of the inversion analysis are the inverted volumes of acoustic impedance $\left(Z_{\mathrm{p}}\right)$ and shear impedance $\left(Z_{\mathrm{s}}\right)$, which are inputted into the Eq. 5 for generation of Poisson impedance, PI volume (Fig. 9).

\section{Results and discussion}

\section{Lithofacies discrimination from Poisson impedance $\log$}

Lithofacies discrimination using Poisson Impedance was designed to correlate with gamma ray signatures for better reservoir resolution. Results based on lithology cut-off
Fig. 6 a Log section showing lithofacies similarities between measured gamma ray $\log$ and Poisson impedance log of well A. Note: sand facies are represented by yellow color while shale facies are gray color. b Lithology discrimination chart between Poisson impedance and gamma ray log showing distributions of various lithofacies

shows that gamma ray and Poisson impedance values less than 65 API and $-100 \mathrm{ft} / \mathrm{s} * \mathrm{~g} / \mathrm{cc}$ represent sand, while values greater than 65API and $-100 \mathrm{ft} / \mathrm{s} * \mathrm{~g} / \mathrm{cc}$ represent shale (Fig. 6a). Well log correlation between Poisson impedance and gamma ray logs over high resistive zones ensure higher confidence in the discrimination and prediction lithofacies and fluid types. Two major lithofacies (sand and shale) and two heteroliths (sandy-shale and shaly-sand) were identified based on Poisson impedance log cross-plot with gamma ray, as shown in Fig. 6b. The validation of Poisson Impedance and gamma ray signatures showed good correlation as lithofacies from well A confirmed that both signatures reflect same as comprising of shales with associated coarsening upward regressive sequence (Fig. 6a).

\section{Lithofacies discrimination and fluid prediction from Poisson impedance inversion}

Successful discrimination of lithofacies from seismic data requires good estimation of seismic wavelet (amplitude and phase spectra) and seismic synthetic to properly fit and calibrate major time events on both log and seismic. Extracted wavelet was observed to be symmetrical with a maximum at time zero (Fig. 7b); this wavelet shape was very useful for increased resolving power and ease of picking reflection events (peak or trough) for seismic scaling and modeling purpose, especially at deeper sections of the seismic. Analysis of the inversion parameters from wells A and C showed that there are some mismatches in the initial and
Fig. 5 Cross-plot of $Z_{\mathrm{p}}$ verses $Z_{\mathrm{s}}$ from three wells used to generate rotation optimization factor, $C_{\mathrm{n}}$ and intercept $Q_{\mathrm{n}}(1.380012$ and 7757.674). Insert: Color code is gamma ray values

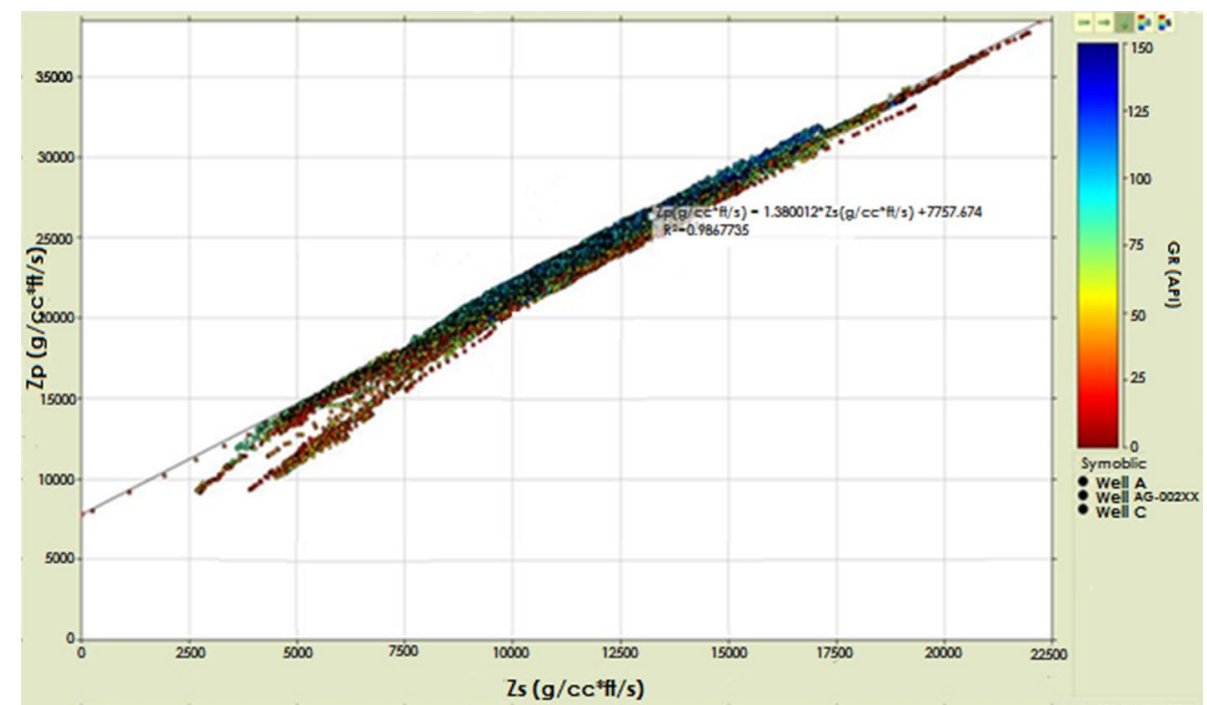



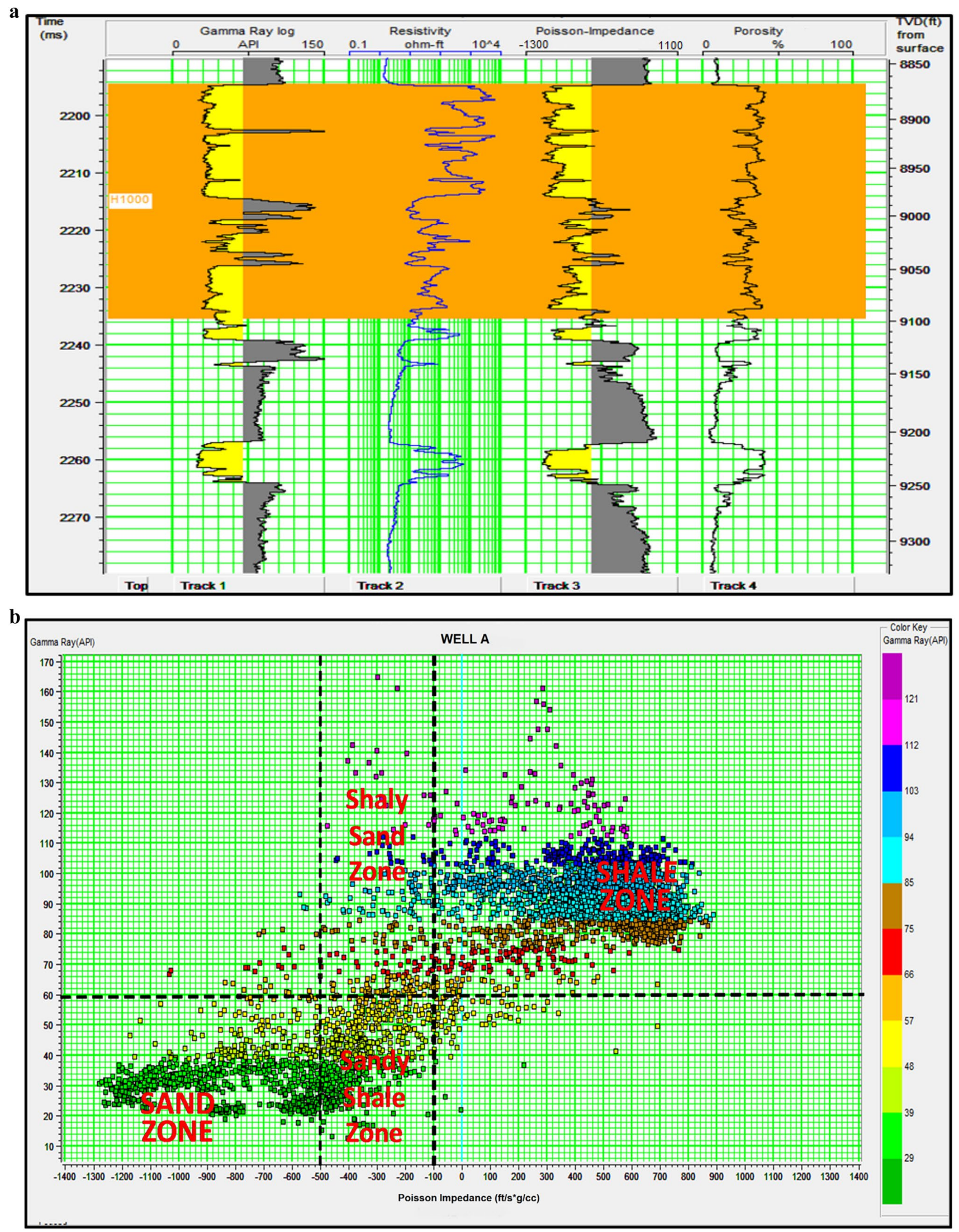


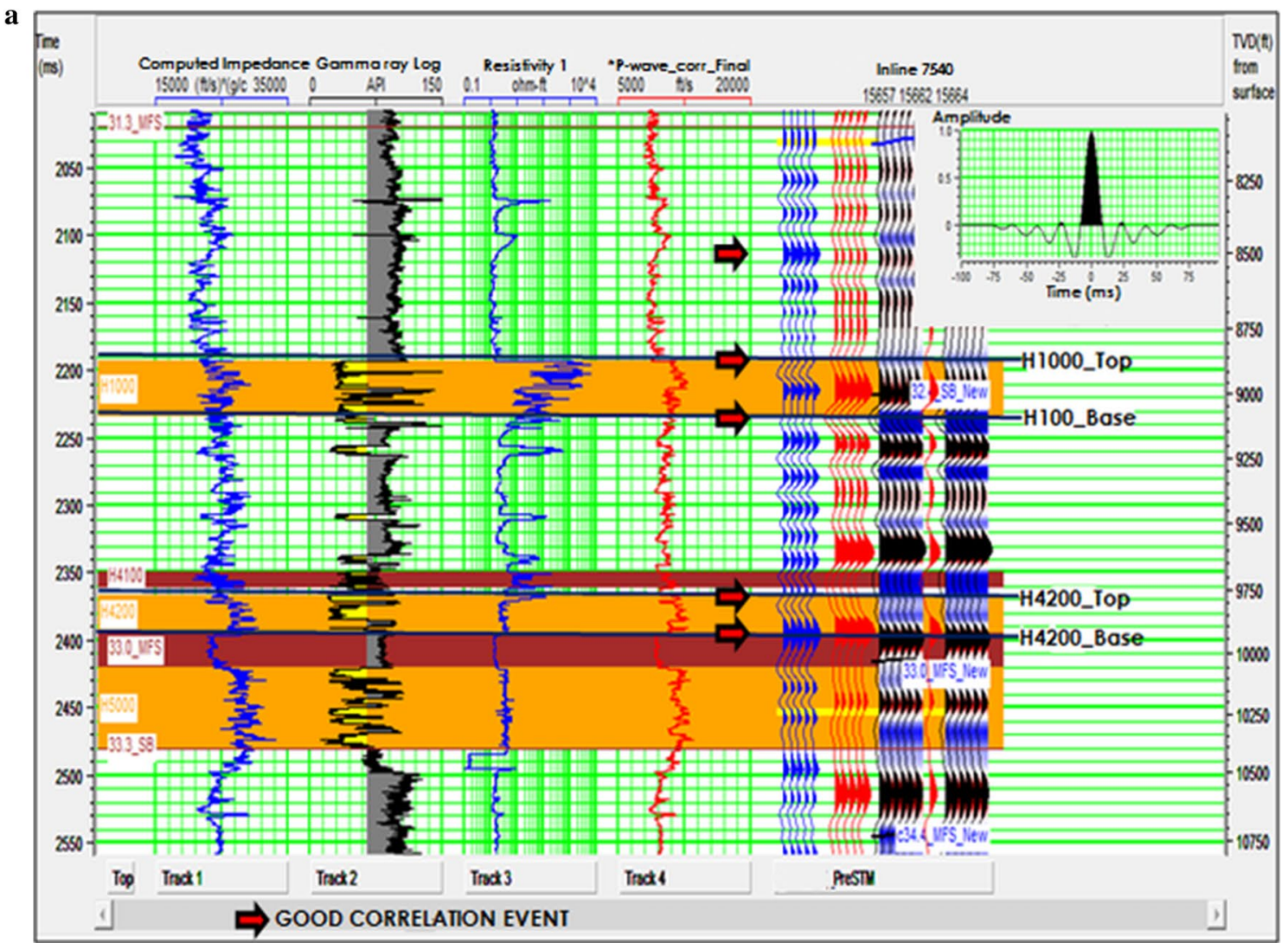

b
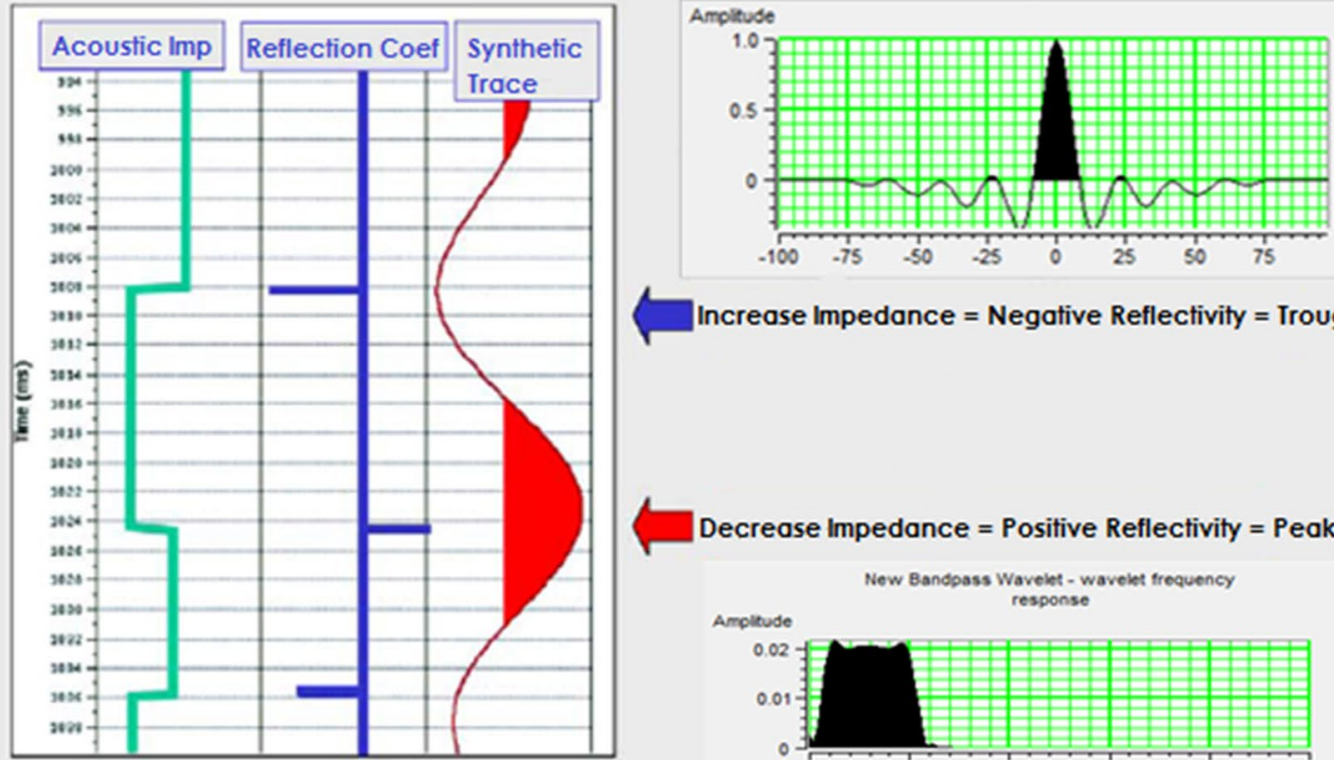

Increase Impedance = Negative Reflectivity = Trough

Decrease Impedance $=$ Positive Reflectivity $=$ Peak
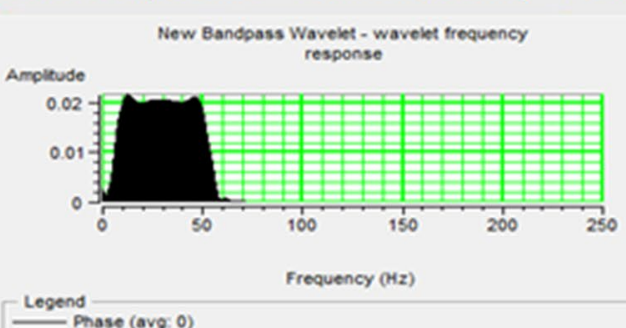

Fig. 7 a Well to seismic section showing synthetic matching with H1 reservoir TOP (as H1000_Top) and BASE (as H1000_Base) as trough event. Insert: extracted zero phased wavelet. b European polarity display, whereby

an increase in acoustic impedance is represented by an excursion to the left (trough) of the seismic loop. Insert: zero-phase wavelet time response at an interval of -15 to $+15 \mathrm{~ms}$, frequency and amplitude band response at $5-60 \mathrm{~Hz}$ 
a

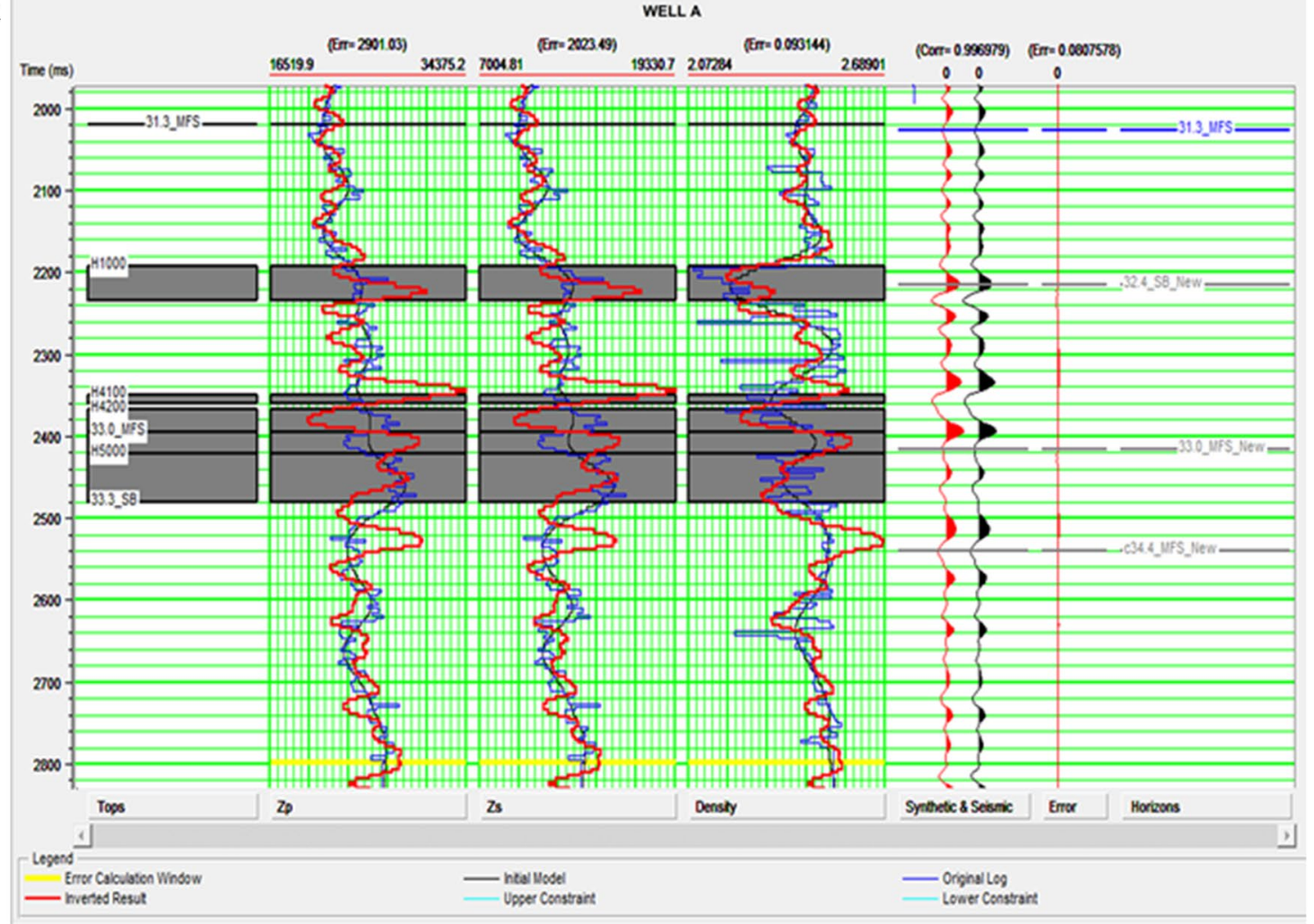

b

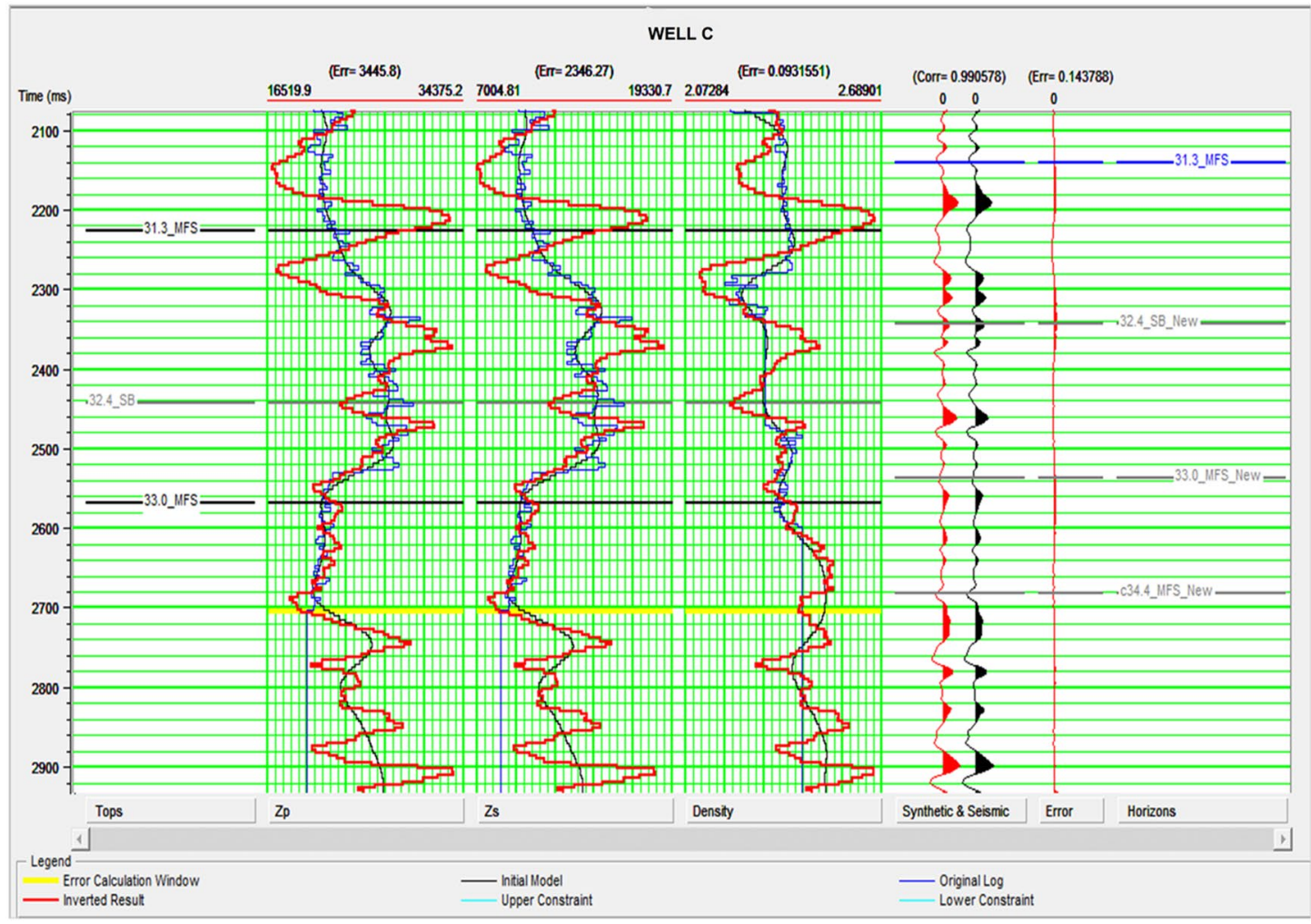

Fig. 8 a Inversion analysis result showing correlation value of 0.996979 with synthetic, seismic and picked horizons after seismic upscaling in well A. b Inversion analysis result showing correlation value of 0.990578 with synthetic, seismic and picked horizons after seismic upscaling in well $\mathrm{C}$ 


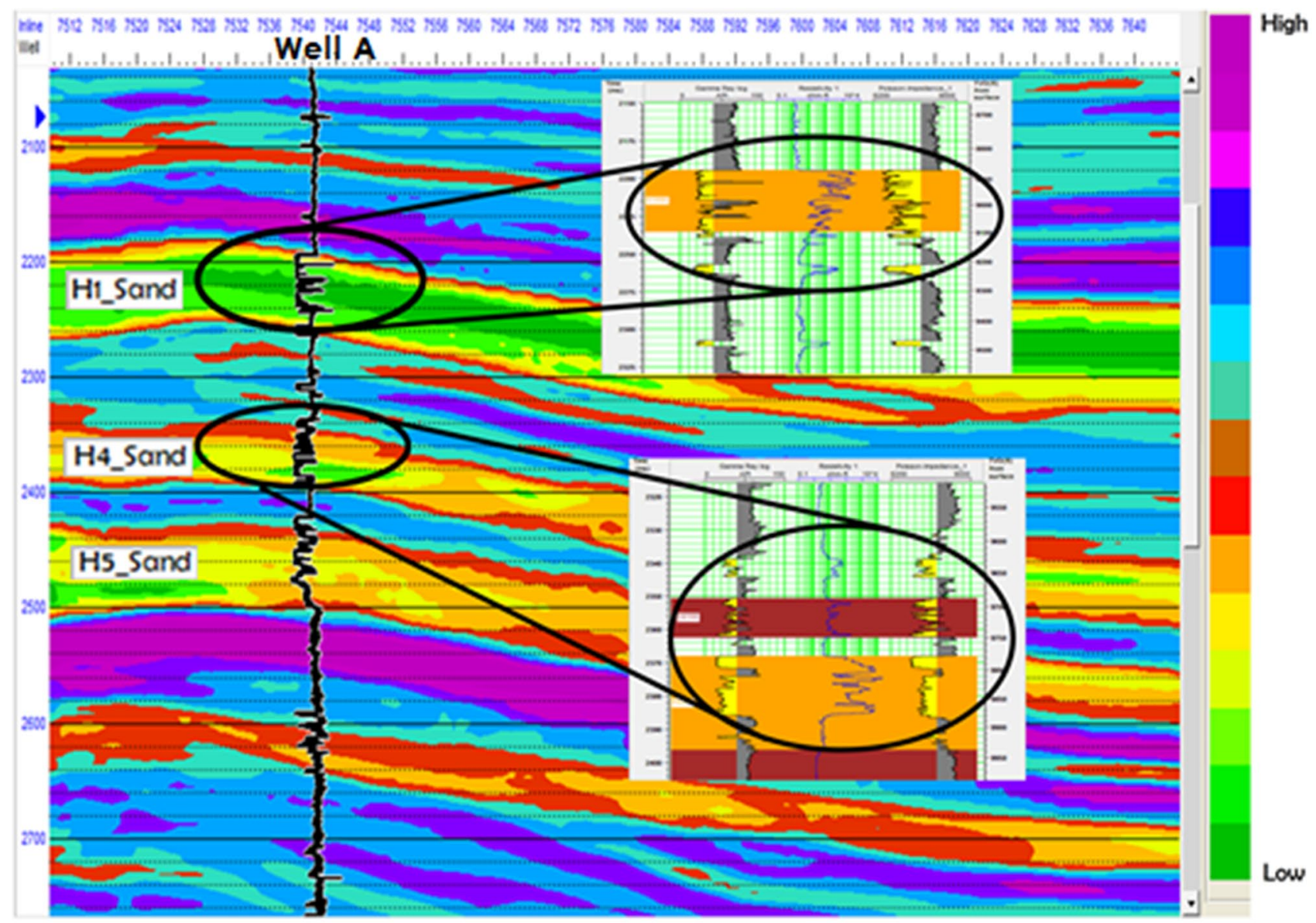

Fig. 9 Crossline section showing inverted Poisson impedance with gamma ray log (insert) over H1, H4 and H5_sands around well A. Note: low values of Poisson impedance correspond to good-quality hydrocarbon sand

original curve of the inverted acoustic impedance $\left(Z_{\mathrm{p}}\right)$ and shear impedance $\left(Z_{\mathrm{s}}\right)$ especially at some interval (Fig. 8). Although this did not affect the inversion result the error estimate between the density, $\rho$, synthetic and seismic traces remains approximately zero. The practical fact behind the observed zero error is that the inversion algorithm has created impedance trace that is consistent with the wavelet and the input seismic trace.

Result from inversion modeling shows that low values of Poisson impedance reflects hydrocarbon-bearing reservoir, while medium to high value represents water (brine) and shale, respectively. On the inverted section, the H1_sand was observed to be hydrocarbon filled, with H4_sand containing brine, and hydrocarbon and H5_sands containing brine only (Fig. 9). Meanwhile, the classification of lithofacies into sand, sandy-shale, shaly-sand and shale combined with the resistivity log made the calibration for fluid types easy to understand and predict in the studied field. In Fig. 10a, the hydrocarbon-filled H1_sand was observed to be laterally continuous even though sedimentation was mainly influenced by the west-north-west to east-south-east (WNW-ESE) trending macrostructure (Fig. 1) which was developed between 34.0 and 29.3 Ma. Observation showed that at well C (basinward), the lithofacies gradually changes from clean hydrocarbon-filled sand to sandy-shale compositions, even though they contain significant amount of hydrocarbon.

Observations based on time slice generated at $2650 \mathrm{~ms}$ show that hydrocarbon-filled reservoirs were mainly distributed along a northeast-southwest trending meandering channel that is away from the drilled wells (Fig. 10b). The implication is that since drilled wells ( $\mathrm{A}$ and $\mathrm{C}$ ) did not penetrate the hydrocarbon-filled sands, the probability of drilling more marginal or dry wells is high unless a concise depositional model is developed to validate the already known structural trappings in the field. 
Fig. 10 a An interception (inline and crossline) section showing the distribution of faults and $\mathrm{H}$-sands in the field. Note: low values of lithology impedance correspond to goodquality hydrocarbon sand. b A map (with inline and crossline) section at $2650 \mathrm{~ms}$ showing the hydrocarbon-filled channel sand in the northeast-southwest direction. Note: low values of Poisson impedance correspond to good-quality hydrocarbon sand
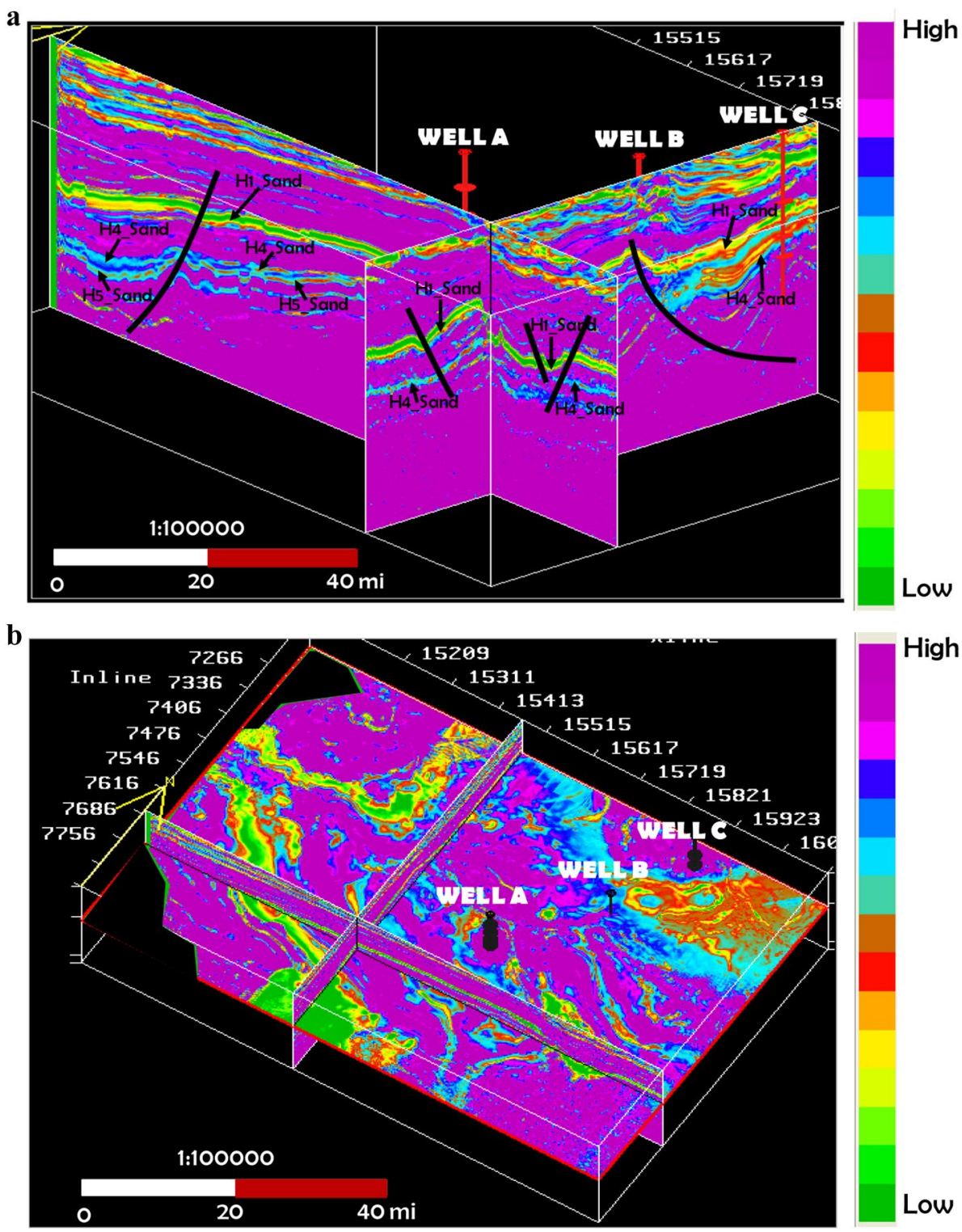

\section{Conclusions}

Poisson impedance (PI) inversion was applied in this study to describe an alternative technique to discriminate lithofacies and predict fluid types in the Eastern Niger Delta basin. The approach takes only the acoustic and shear impedances $\left(Z_{\mathrm{p}}\right.$ and $\left.Z_{\mathrm{s}}\right)$ into consideration; it is relatively simple and can be adapted in other fields in the Niger Delta Basin with regular sedimentation and tectonic activities. Four categories of lithofacies type (clean sand, sandy-shale, shaly-sand and shale) have been discriminated based on the well log cross-plot between gamma ray and Poisson impedance. The cross-plot revealed clearly very good-quality sand (sand zone), good quality (sandy-shale zone), and poor-quality sands (shaly-sand zone) from shale. Poisson impedance values obtained from the application of prestack simultaneous inversion show those values with less than $-100 \mathrm{ft} / \mathrm{s} * \mathrm{~g} /$ cc (low) as representing hydrocarbon-filled sand, whereas greater values (medium and high) represent brine and shale. The result shows that these value ranges are roughly in an acceptable agreement with the gamma ray values used for discriminating lithofacies. The validation of this technique in 3-D space revealed that the distribution of hydrocarbonfilled reservoirs was mainly distributed along a northeast-southwest trending meandering channel and that most drilled wells possibly did not penetrate the hydrocarbonfilled sands, thus leading to abandonment of wells as marginal or dry wells. Presently, exploration programs in some fields in Niger Delta basin are more commonly designed to reduce cost and increase exploration success rate so that the number of dry wells and drilling risks may be decreased if well calibrated. Finally, the methodology presented in the 
paper has both a cognitive and practical aspect since it is essential for locating new sites for the drilling of new in-fill wells in areas without well control.

Acknowledgements The authors gratefully acknowledge the Shell Petroleum Development Company SPDC, Port Harcourt, Nigeria, for providing the dataset used for this study during Doctoral Research Internship program, and Petroleum Technology Development Fund (PTDF) Chair of Petroleum Geology, University of Nigeria, Nsukka, Nigeria, for the support and enabling environment for this study.

Open Access This article is distributed under the terms of the Creative Commons Attribution 4.0 International License (http://creativeco mmons.org/licenses/by/4.0/), which permits unrestricted use, distribution, and reproduction in any medium, provided you give appropriate credit to the original author(s) and the source, provide a link to the Creative Commons license, and indicate if changes were made.

\section{References}

Aki K, Richards PG (1980) Quantitative seismology: theory and methods: W. H. Freeman and Co., New York

Coulon JP, Lafet Y, Deschuzeaux B, Doyen PM, Duboz P (2006) Stratigraphic elastic Inversion for seismic Lithology discrimination in a Turbiditic Reservoir, SEG Extended Abstract, pp 2092-2096

Doust H, Omatsola E (1989) Niger Delta. Am Assoc Pet Geol Bull 48:201-238

Doust H, Omatsola E (1990) Niger Delta. In: Edwards JD, Santogrossi PA (eds) Divergent/passive margin basins, AAPG memoir 48. American Association of Petroleum Geologists, Tulsa, pp 239-248

Duboz P, Lafet Y, Mougenot D (1998) Moving to a layered impedance cube: advantages of 3D stratigraphic inversion. First Break 16(9):311-318

Ekwe AC, Onuoha KM, Osanyande N (2012) Fluid and lithology discrimination using rock physics modeling and Lambda-Mu-Rho inversion: an example from onshore Niger Delta, Nigeria. Search and discovery article \#40865, pp 11

Evamy BD, Haremboure J, Kamerling P, Knaap WA, Molloy FA, Rowlands PH (1978) Hydrocarbon habitat of Tertiary Niger Delta. Am Assoc Pet Geol Bull 62:277-298

Farfour M, Yoon WJ, Kim J (2015) Seismic attributes and acoustic impedance inversion in interpretation of complex hydrocarbon reservoirs. J Appl Geophys 114:68-80

Fatti JL, Smith GC, Vail PJ, Strauss PJ, Levitt PR (1994) Detection of gas in sandstone reservoirs using AVO analysis: a 3-D seismic case history using the Geostack technique. Geophysics 59:1362-1376

Goodway B, Chen T, Downton J (1997) Improved AVO fluid detection and lithology discrimination using Lamé petrophysical parameters: $\lambda \rho, \mu \rho, \& \lambda / \mu$ fluid stack, from P and S inversions: 67th annual international meeting, SEG, Expanded Abstracts, pp 183-186

Hampson DP, Russell BH, Bankhead B (2005) Simultaneous inversion of pre-stack seismic data, 75th SEG Meetings, SEG Expanded Abstracts, pp 1633-1636

Lawrence SR, Monday S, Bray R (2002) Regional geology and geophysics of the eastern Gulf of Guinea (Niger Delta to Rio Muni). Lead Edge 21:1112-1117

Ma XQ (2002) Simultaneous inversion of Prestack seismic data for rock properties using simulated annealing. Geophysics 67:18771885. https://doi.org/10.1190/1.1527087

Mazumdar P (2007) Poisson damping factor. Lead Edge 26:850-851. https://doi.org/10.1190/1.2756862

Nair KN, Kolbjørnsen O, Skorstad A (2012) Seismic inversion and its applications in reservoir characterization. First Break 30:83-86
Nwogbo PO, Omudu M, Dike R, Olotu S, Osayande N (2009) Seismicbased lithology and fluid delineation of the ROK reservoir sand, shallow offshore Niger Delta. In: SEG Technical Program Expanded Abstracts 2009, pp 608-612. https://doi.org/10.1190/1.3255830

Omudu LM, Ebeniro JO, Xynogalas M, Adesanya O, Osayande N (2007) Beyond acoustic impedance: an onshore Niger Delta experience. In: SEG/San Antonio Annual Meeting, pp 412-415

Orife JM, Afbovbo AA (1981) Stratigraphic and unconformity traps in the Niger delta-Abstract. Am Assoc Pet Geol Bull 65:251-265

Petters SW (1984) An ancient submarine canyon in the OligoceneMiocene of the western Niger Delta. Sedimentology 31:805-810

Quakenbush M, Shang B, Tuttle C (2006) Poisson impedance. Lead Edge 25(2):128-138. https://doi.org/10.1190/1.2172301

Reijers TJA (2011) Stratigraphy and sedimentology of the Niger-Delta. Geologos 17(3):133-162

Reijers T, Petters S, Nwajide C (1997). In: Selley RC (ed) The Niger Delta Basin, African Basins-Sedimentary Basin of the World 3. Elsevier Science, Amsterdam, pp 151-172

Russell BA (2014) Prestack seismic amplitude analysis: an integrated overview. Interpretation 2(2):SC19-SC36. https://doi. org/10.1190/INT-2013-0122.1

Sen MK (2006) Seismic inversion. Society of Petroleum Engineers (SPE), pp 120. ISBN: 978-1-55563-110-9

Sharma RK, Chopra S (2013) Poisson impedance inversion for characterization of sandstone reservoirs, SEG/Houston Annual Meeting, pp 2549-2553. https://doi.org/10.1190/segam2013-0181.1

Short KC, Stauble AJ (1967) Outline of geology of Niger Delta. Am Asso Petrol Geol Bull 51:761-779

Singh V, Srivastava AK, Painuly PK (2007) Neural networks and their applications in lithostratigraphic interpretation of seismic data for reservoir characterization. Lead Edge 26(10):1244-1260

Singleton SW (2011) The effects of seismic data conditioning on prestack simultaneous impedance inversion: GCSSEPM 31st Annual Bob. F. Perkins Research Conference, pp 35-65

SPDC Internal Report (2007) Onshore to deep water geologic integration, Niger Delta. In: Ejedawa J, Love F, Steele D, Ladipo K (eds) Presentation packs of Shell Exploration and Production Limited, Port-Harcourt (unpublished)

Stacher P (1995) Present understanding of the Niger Delta hydrocarbon habitat. In: Oti MN, Postma G (eds) Geology of Deltas. A.A. Balkema, Rotterdam, pp 257-267

Tian L, Zhou D, Lin G, Jiang L (2010) Reservoir prediction using Poisson Impedance in Quinhuangdao, Bohai Sea: SEG Denver 2010 Annual Meeting, pp 2261-2264

Tucovic N, Bartetzko A, Wessling S, Schön J, Gegenhuber N (2016) Resistivity and acoustic impedance based rock physics templates for enhanced well placement and reservoir understanding. In: 78th EAGE conference and exhibition, extended abstracts, We STZ013

Ujuanbi O, Okolie JC, Jegede SI (2008) Lambda-Mu-Rho techniques as a viable tool for litho-fluid discrimination. The Niger Delta example. Int J Phys Sci 2/7:173-176

Veeken PC, Da Silva M (2004) Seismic inversion methods and some of their constraints. First Break 22(6):47-70

Wang Y (1999) Simultaneous inversion for model geometry and elastic parameters. Geophysics 64:182-190

Whiteman A (1982) Nigeria: its petroleum geology, resources and potential. Graham and Trotman, London, pp 394

Zhou ZY, Hilterman FJ (2010) A comparison between methods that discriminate fluid content in unconsolidated sandstone reservoirs. Geophysics 75(1):B47-B58. https://doi.org/10.1190/1.3253153

Publisher's Note Springer Nature remains neutral with regard to jurisdictional claims in published maps and institutional affiliations 